\title{
PENERAPAN MEDIA WIRECAST PADA KONSEP LISTRIK DINAMIS UNTUK MENINGKATKAN PRESTASI BELAJAR SISWA DI SMA NEGERI 2 PROBOLINGGO
}

\author{
Nurhayati Ningsih \\ SMAN 2 Probolinggo \\ nurhayatiningsih@gmail.com
}

\begin{abstract}
Abstrak
Penelitian ini bertujuan untuk mendeskripsikan peningkatan prestasi belajar siswa pada konsep listrik dinamis dan mendeskripsikan respons siswa terhadap pembelajaran melalui media Wirecast di SMA Negeri 2 Probolinggo. Desain penelitian ini mengadaptasi dari Kemmis dan Taggart. Jenis penelitian ini adalah penelitian tindakan kelas. Hasil penelitian menunjukkan bahwa penerapan media Wirecast dapat meningkatkan prestasi belajar siswa, dan respon siswa terhadap penerapan media Wirecast sangat setuju. Persentase prestasi belajar Siswa pada siklus I adalah 62,96\%, siklus II adalah 81,48 \% dan siklus III adalah 96,29\%. Dengan demikian pembelajaran dengan menggunakan media wirecast dapat meningkatkan prestasi belajar siswa dan respons siswa sangat positif.
\end{abstract}

\section{Kata kunci: Wirecast, Media Pembelajaran, Listrik Dinamis, Prestasi Belajar}

\section{Pendahuluan}

Fisika merupakan ilmu yang mempunyai peranan penting dalam perkembangan ilmu pengetahuan dan teknologi. Siswa di sekolah memandang fisika sebagai bidang studi yang paling sulit, padahal fisika merupakan mata pelajaran yang banyak berguna dalam kehidupan dan merupakan salah satu mata pelajaran yang diujikan dalam UN. Fisika merupakan sarana berpikir logis untuk memecahkan masalah kehidupan sehari-hari. SMA Negeri 2 Probolinggo mempunyai 22 kelas, kelas X tujuh kelas, kelas XI tujuh kelas dan kelas XII delapan kelas masing-masing terdiri dari 25-35 siswa. Berdasarkan hasil wawancara dengan guru fisika prestasi belajar siswa kelas X tahun pelajaran 2017/2018 ratarata rendah, hal ini dapat dilihat dari hasil ulangan fisika yang rata-rata dibawah KKM, khusus untuk kelas X MIPA 1, setiap diadakan ulangan harian fisika rata-rata siswa yang tuntas hanya $50 \%$, dimana KKM fisika untuk siswa kelas X MIPA 1 adalah 75.

Berdasarkan hasil wawancara dengan guru fisika, sebagian besar proses pembelajaran fisika berpusat pada guru (teacher oriented), dan pembelajaran lebih didominasi informasi dari guru dalam menjelaskan konsep fisika tanpa ditunjang dengan media yang menarik. Dengan menggunakan metode ceramah, aktivitas yang dilakukan siswa hanya mendengarkan dan mencatat, sehingga siswa kurang dalam mengemukakan pertanyaan dan pendapatnya. Diskusi antar kelompok sedikit dilakukan sehingga interaksi dan komunikasi antar siswa dengan siswa lainnya maupun dengan guru masih belum maksimal selama proses pembelajaran, bukan tanpa alasan banyak guru fisika menggunakan metode ceramah, salah satu alasannya adalah jam kegiatan belajar mengajar (KBM) untuk mata pelajaran fisika hanya tiga jam pelajaran, sehingga guru fisika cenderung lebih memilih metode ceramah karena materi lebih cepat selesai. Guru fisika banyak yang mengeluh tentang jam mengajar fisika yang sedikit tetapi materi fisika begitu banyak bahkan ada beberapa materi yang belum tersampaikan, oleh karena itu seringkali soal-soal fisika diselesaikan dengan cara cepat dimana siswa belum bisa memahami konsep fisika secara mendalam. Berdasarkan uraian tersebut, peneliti ingin menggunakan metode dan media pembelajaran yang praktis, jelas dan berbobot dalam pelajaran fisika sehingga siswa mudah dalam memahami konsep fisika serta interaksi dan komunikasi antar siswa terjalin dengan baik dan sangat kolaboratif dalam membahas konsep fisika. 
Berdasarkan masalah tersebut peneliti ingin melakukan proses perbaikan dalam pembelajaran fisika khususnya kelas X MIPA 1. Hal ini dilakukan dengan tujuan agar siswa dapat ikut aktif selama proses pembelajaran berlangsung. Siswa saling bertukar pendapat dalam memahami konsep fisika serta mampu menyelesaikan soal fisika secara diskusi dalam kelompok, maka diperlukan metode dan media pembelajaran yang dapat mengaktifkan siswa selama proses pembelajaran. Metode pembelajaran yang mendorong keaktifan, kemandirian dan tanggung jawab dalam diri siswa adalah metode diskusi dan media yang tepat untuk digunakan adalah media Wirecast, dengan harapan dapat meningkatkan keaktifan dan prestasi siswa. Berdasarkan uraian diatas maka peneliti mengadakan penelitian dengan judul "Penerapan Media Wirecast Pada Konsep Listrik Dinamis Untuk Meningkatkan Prestasi Belajar Siswa Di SMA Negeri 2 Probolinggo". Penelitian ini dilakukan untuk mengetahui apakah pembelajaran fisika dengan menggunakan media Wirecast dapat meningkatkan prestasi belajar siswa serta bagaimana respons siswa terhadap media Wirecast ini.

Tujuan penelitian ini adalah mendeskripsikan peningkatan prestasi belajar siswa pada konsep Listrik Dinamis dan mendeskripsikan respon siswa terhadap proses pembelajaran melalui media Wirecast di SMA Negeri 2 Probolinggo. Ruang lingkup dalam penelitian ini adalah Penelitian ini dilakukan pada siswa Kelas X MIPA 1 di SMA Negeri 2 Probolinggo, aspek yang diamati dapat dilihat dari hasil prestasi belajar siswa setelah dilakukan tes siklus pada konsep Listrik Dinamis, dan respons siswa dapat dilihat pada angket siswa terhadap penggunaan media Wirecast.

\section{Tinjauan Pustaka}

\section{Prestasi Belajar}

Prestasi belajar adalah hasil yang dicapai seseorang dalam penguasaan pengetahuan dan keterampilan yang dikembangkan dalam pelajaran, lazimnya ditunjukkan dengan tes angka nilai yang diberikan oleh guru (Asmara; 2009). Pengetahuan, pengalaman dan keterampilan yang diperoleh akan membentuk kepribadian siswa, memperluas wawasan kehidupan serta meningkatkan kemampuan siswa, dan belajar merupakan perubahan tingkah laku atau penampilan dengan serangkaian kegiatan.

\section{Media Pembelajaran}

Media pembelajaran adalah segala sesuatu yang dapat menyampaikan atau menyalurkan pesan dari sumber secara terencana, sehingga terjadi lingkungan belajar yang kondusif dimana penerimanya dapat melakukan proses belajar secara efisien dan efektif (Asyar, Rayanda; 2012). Fungsi media pembelajaran menurut Hamalik, Oemar (2008), yaitu: (1) Untuk mewujudkan situasi pembelajaran yang efektif; (2) Untuk mempercepat proses pembelajaran dan membantu siswa dalam upaya memahami materi yang disajikan oleh guru dalam kelas; dan (3) Meningkatkan mutu pendidikan.

\section{Wirecast}

Wirecast adalah sebuah software yang memungkinkan orang-orang untuk menyiarkan pertunjukan secara live yang dapat membuat sebuah video pembelajaran interaktif di dalamnya dan Wirecast ini bisa dikatakan sebagai pemrosesan dari bahan-bahan pembuatan media pembelajaran yang sudah ada. Berikut bahan-bahan yang digunakan untuk membuat video pembelajaran interaktif dengan menggunakan aplikasi Wirecast: (1) Controller, untuk mengelola video pembelajaran ini tentunya dibutuhkan sebuah controller yang digunakan untuk proses pengolahan video tersebut; (2) Green/Blue Screen (Latar Belakang), Screen atau latar belakang ini digunakan untuk membuat efek dari chroma key atau mengganti latar belakang yang sesungguhnya dengan gambar, video, animasi dan lain-lain; (3) Microphone, Microphone digunakan untuk mentransfer suara dari presenter ke controller.

\section{Materi Listrik Dinamis}

Listrik Dinamis merupakan salah satu materi pelajaran yang diberikan pada siswa SMA kelas X MIPA. Listrik Dinamis adalah listrik 
yang dapat bergerak. Kuat arus pada rangkaian bercabang sama dengan kuat arus yang masuk sama dengan kuat arus yang keluar. Sedangkan pada rangkaian seri kuat arus tetap sama di setiap ujung-ujung hambatan. Pada rangkaian seri tegangan sangat tergantung pada hambatan, tetapi pada rangkaian bercabang tegangan tidak berpengaruh pada hambatan. Semua itu telah dikemukakan oleh Hukum Kirchoff yang berbunyi "jumlah kuat arus listrik yang masuk sama dengan jumlah kuat arus listrik yang keluar".

\section{Metode Penelitian}

\section{Desain Penelitian}

Jenis penelitian ini adalah penelitian tindakan kelas, dimana dalam penelitian ini, peneliti meminta bantuan teman sejawat untuk mengamati kegiatan proses belajar mengajar. Menurut Kemmis dan taggart ada beberapa tahapan dalam penelitian ini, yaitu: (1) Perencanaan; (2) Tindakan; (3) Pengamatan; dan (4) Refleksi. Dalam penelitian ini dilakukan dalam tiga siklus. Siklus dihentikan apabila kondisi kelas sudah stabil, dalam hal ini guru sudah mampu menguasai ketrampilan belajar yang baru dan siswa terbiasa dengan media wirecast dalam pembelajaran dimana dalam hal ini siswa sudah mengalami peningkatan keaktifan dan prestasi belajar. Alur penelitian, yaitu:

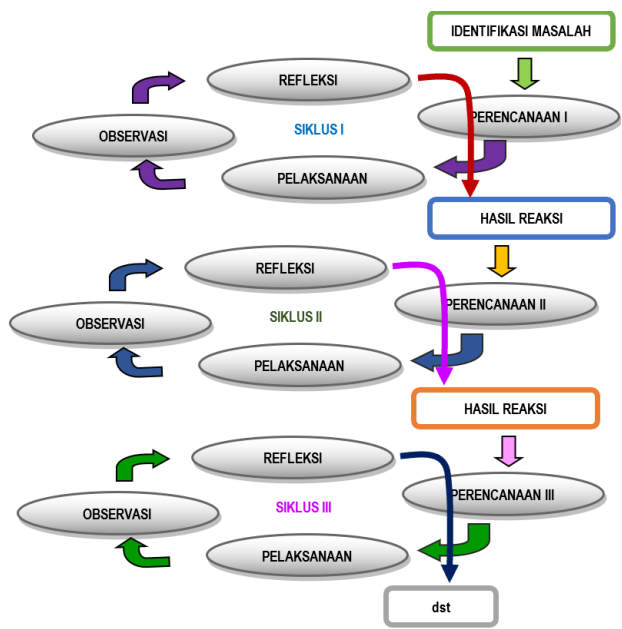

Gambar 3.1. Model Spiral dari Kemmis dan Taggart

\section{Tahapan Penelitian}

\section{Tahapan Penelitian Siklus I}

\section{Perencanaan}

Pada tahap ini peneliti mempersiapkan silabus, rencana pelaksanaan pembelajaran (RPP), membuat power point untuk ditampilkan dalam video wirecast, membuat video serta rekaman dengan media Wirecast, membuat soal kuis, kisi-kisi, soal tes siklus, lembar observasi dan lembar angket respon siswa.

\section{Tindakan}

Pelaksanaan tindakan pada siklus pertama dilakukan dalam dua kali pertemuan dengan waktu satu jam pelajaran (45 menit) dan pertemuan kedua dengan waktu dua jam pelajaran (90 menit). Tahap tindakan dilakukan oleh guru dengan menggunakan media Wirecast dalam pembelajaran.

\section{Observasi}

Dilakukan selama proses pembelajaran dengan menggunakan lembar observasi yang telah disiapkan dan mencatat kejadian-kejadian yang tidak terdapat dalam lembar observasi dengan membuat lembar catatan lapangan.

\section{Refleksi}

Pada tahap ini peneliti bersama teman sejawat melakukan evaluasi dari pelaksanaan tindakan pada siklus I yang digunakan sebagai bahan pertimbangan perencanaan pembelajaran siklus berikutnya. Jika hasil yang diharapkan belum tercapai maka dilakukan perbaikan yang dilaksanakan pada siklus kedua dan seterusnya.

Tahapan Penelitian Siklus II dan Siklus III Rencana tindakan siklus II dimaksudkan sebagai hasil refleksi dan perbaikan terhadap pelaksanaan pembelajaran pada siklus I. Sedangkan kegiatan pada siklus III dimaksudkan sebagai hasil refleksi dan perbaikan terhadap pelaksanaan pembelajaran pada siklus II. Tahapan tindakan siklus II dan Siklus III mengikuti tahapan tindakan siklus I. 


\section{Teknik Pengumpulan Data}

\section{Observasi}

Observasi prestasi siswa difokuskan pada hasil belajar siswa pada materi Listrik Dinamis. Sedangkan respon siswa difokuskan pada angket yang diberikan oleh peneliti selama proses pembelajaran.

\section{Angket}

Angket dibagikan dan diisi oleh siswa untuk mengetahui respons siswa terhadap pelaksanaan pembelajaran fisika melalui media Wirecast.

\section{Wawancara}

Wawancara dilakukan dengan cara bertanya kepada guru dan siswa mengenai proses pembelajaran melalui media Wirecast.

\section{Tes}

Tes digunakan berupa kuis dan tes siklus yang fungsinya untuk mengetahui tingkat pemahaman siswa setelah menyimak rekaman video materi Listrik Dinamis melalui media Wirecast.

\section{Dokumentasi}

Dokumentasi diperoleh dari hasil kuis dan tes siklus siswa, lembar observasi, catatan lapangan, daftar kelompok siswa, video melalui media Wirecast dan foto-foto selama proses pembelajaran.

\section{Teknik Analisis Data}

Data yang diperoleh dari tindakan yang dilakukan dianalisis untuk memastikan bahwa pembelajaran melalui media Wirecast pada mata pelajaran fisika materi Listrik Dinamis dapat meningkatkan prestasi belajar siswa kelas X MIPA 1 SMA Negeri 2 Probolinggo. Adapun analisis data yang digunakan, yaitu:

\section{Analisis Hasil Prestasi Siswa}

Hasil tes siswa dianalisis untuk menentukan peningkatan ketuntasan siswa, nilai individu, skor kelompok dan penghargaan kelompok.

Peningkatan ketuntasan mengikuti ketentuan sekolah bahwa "siswa dinyatakan lulus dalam setiap tes jika nilai yang diperoleh $\geq 75$ dengan nilai maksimum 100". Maka dalam penelitian ini juga menggunakan ketentuan yang ditetapkan sekolah untuk menentukan persen (\%) ketuntasan siswa dengan menggunakan perhitungan persen (\%) ketuntasan sebagai berikut:

Persentase $(\%)$ Ketuntasan $=($ Jumlah siswa tuntas)/(Jumlah siswa ) x 100\%

Peningkatan prestasi siswa juga dilihat dari hasil belajar jangka pendeknya yang ditunjukkan dengan kenaikan nilai rata-rata tes pada setiap siklus. Dari data perolehan skor untuk setiap tes, rata-rata nilai siswa dengan menggunakan perhitungan sebagai berikut:

Persentase $(\%)$ Ketuntasan $=$ $\frac{\text { Jumlah siswa tuntas }}{\text { Jumlah siswa }} \times 100 \%$

Peningkatan nilai individu siswa diperoleh dengan membandingkan skor dasar siswa (ratarata nilai tes siswa sebelumnya) dengan nilai tes sekarang.

Perolehan penghargaan kelompok dengan melihat jumlah rata-rata skor tiap kelompok.

\section{Analisis Angket Respons Siswa}

Angket respons siswa merupakan sejumlah pertanyaan tertulis yang digunakan untuk memperoleh data tentang respons siswa terhadap pembelajaran dengan menggunakan media Wirecast. Angket respons siswa terdiri dari 10 butir pertanyaan. Skala pengukuran yang digunakan adalah skala Likert. Dalam skala ini pernyataan-pernyataan yang diajukan dinilai oleh siswa dengan sangat setuju, setuju, netral, tidak setuju dan sangat tidak setuju, dengan perhitungan persentase sebagai berikut:

$$
\bar{X}=\frac{\sum X}{\sum N} \begin{aligned}
& \text { dengan } \bar{X}=\text { nilai rata-rata } \\
& \sum X=\text { jumlah semua nilai siswa } \\
& \sum N=\text { jumlah siswa }
\end{aligned}
$$

\section{HASIL PENELITIAN DAN PEMBAHASAN}

\section{Pelaksanaan Tindakan Siklus I}

Pada tahap pelaksanaan tindakan, media Wirecast ini memuat tentang penjelasan konsep Hukum I Kirchoff dan Hukum II Kirchoff untuk satu loop serta contoh soalnya.

\section{Analisis Data Siklus I}

Berdasarkan hasil tes pada siklus I disajikan seperti tabel di bawah ini: 
Tabel 1 Tabel Prestasi Belajar siswa pada Siklus 1

\begin{tabular}{llccc}
\hline No & $\begin{array}{l}\text { Nama } \\
\text { Siswa }\end{array}$ & Nilai & \multicolumn{2}{c}{ Kriteria } \\
\cline { 2 - 5 } & & & $\begin{array}{c}\text { Tun- } \\
\text { tas }\end{array}$ & $\begin{array}{c}\text { Tidak } \\
\text { Tuntas }\end{array}$ \\
\hline 1 & ABG & 70 & - & TT \\
\hline 2 & AAN & 76 & T & \\
\hline 3 & AW & 65 & - & TT \\
\hline 4 & DIS & 77 & T & \\
\hline 5 & DA & 89 & T & \\
\hline 6 & FR & 79 & T & \\
\hline 7 & FBS & 85 & T & \\
\hline 8 & GAA & 79 & T & \\
\hline 9 & IAL & 59 & - & TT \\
\hline 10 & KEC & 72 & - & TT \\
\hline 11 & KSN & 70 & - & TT \\
\hline 12 & LVR & 81 & T & \\
\hline 13 & LNU & 80 & T & \\
\hline 14 & LAG & 84 & T & \\
\hline 15 & M & 54 & - & TT \\
\hline 16 & MF & 81 & T & \\
\hline 17 & MM & 72 & - & TT \\
\hline 18 & NJA & 83 & T & \\
\hline 19 & NMRA & 65 & - & TT \\
\hline 20 & ND & 70 & - & TT \\
\hline 21 & RKW & 70 & - & TT \\
\hline 22 & RMW & 81 & T & \\
\hline 23 & RNGP & 81 & T & \\
\hline 24 & SSA & 76 & T & \\
\hline 25 & TT & 96 & T & \\
\hline 26 & YRKP & 83 & T & \\
\hline 27 & YDMS & 94 & T & \\
\hline Jumlah & 2073 & 17 & 10 \\
\hline Rata-rata & 76,78 & & \\
\hline Ketuntasan & 62,96 & & \\
\hline Klasikal & & & \\
\hline & & & & \\
\hline & & & \\
\hline & & & \\
\hline & & & \\
\hline & & & \\
\hline
\end{tabular}

Berdasarkan tabel diketahui bahwa skor terendah 54 dan skor tertinggi 96. Jumlah siswa yang tidak tuntas atau belum mencapai KKM sebanyak 10 siswa, sehingga persentase ketuntasan atau daya serap klasikal adalah sebagai berikut:

Persentase $=\frac{\text { Jumlah siswa yang tuntas }}{\text { Jumlah siswa keseluruhan }} \times 100 \%$ Persentase $=\frac{17}{27} \times 100 \%=62,96 \%$

Ketuntasan belajar secara klasikal yang dicapai pada siklus I sebesar $62,96 \%$, sehingga dapat dikatakan kelas tersebut belum tuntas belajar, karena belum mencapai $85 \%$ siswa yang telah mencapai daya serap. Kemudian rata-rata kelas dapat dihitung sebagai berikut:

Rata - rata $=\frac{\text { Jumlah semua nilai siswa }}{\text { Jumlah siswa }}$

$$
\text { Rata }- \text { rata }=\frac{2073}{27}=76,78
$$

Rata-rata kelas yang dicapai pada siklus I sebesar 76,78, sehingga dapat dikatakan ratarata kelas belum maksimal, karena belum mencapai 85. Berdasarkan hasil observasi dan hasil evaluasi yang diperoleh pada siklus I, ada beberapa catatan penting yang harus diperhatikan, antara lain:

1. Saat menyimak video melalui media Wirecast, ada beberapa siswa yang belum maksimal dalam memperhatikan video tersebut, bahkan ada siswa yang bersenda gurau dengan temannya.

2. Waktu 50 menit untuk menyimak video belum cukup bagi siswa.

3. Ketua Kelompok (sang leader) belum maksimal dalam mengatur anggota kelompoknya dan tidak jelas dalam menerangkan materi sehingga masih ada beberapa siswa yang belum paham tentang materi tersebut.

\section{Pelaksanaan Tindakan Siklus II}

Pada pelaksanaan tindakan untuk siklus yang kedua ini penerapan tindakannya berulang sama dengan siklus pertama, yaitu tetap menggunakan media Wirecast hanya saja ada perubahan ketua kelompok (sang leader), hal ini untuk memotivasi siswa agar mereka termotivasi untuk menyimak video dengan sungguh-sungguh, dengan tujuan agar nilai mereka meningkat sehingga mereka tidak 
malu mendengarkan nilai yang dibacakan oleh peneliti. Hal ini menarik karena menciptakan persaingan belajar yang sehat sehingga suasana diskusi kelompok lebih hidup, menarik dan menyenangkan.

\section{Analisis Data Siklus II}

Berdasarkan hasil tes pada siklus II disajikan seperti tabel di bawah ini:

Tabel 2 Tabel Hasil Belajar siswa pada Siklus II

\begin{tabular}{|c|c|c|c|c|}
\hline \multirow[b]{2}{*}{ No } & \multirow{2}{*}{$\begin{array}{l}\text { Nama } \\
\text { Siswa }\end{array}$} & \multirow[b]{2}{*}{ Nilai } & \multicolumn{2}{|c|}{ Kriteria } \\
\hline & & & Tuntas & $\begin{array}{c}\text { Tidak } \\
\text { Tuntas }\end{array}$ \\
\hline 1 & $\mathrm{ABG}$ & 70 & - & TT \\
\hline 2 & AAN & 76 & $\mathrm{~T}$ & - \\
\hline 3 & AW & 100 & $\mathrm{~T}$ & - \\
\hline 4 & DIS & 65 & - & TT \\
\hline 5 & $\mathrm{DA}$ & 80 & $\mathrm{~T}$ & - \\
\hline 6 & FR & 100 & $\mathrm{~T}$ & - \\
\hline 7 & FBS & 78 & $\mathrm{~T}$ & - \\
\hline 8 & GAA & 95 & $\mathrm{~T}$ & - \\
\hline 9 & IAL & 100 & $\mathrm{~T}$ & - \\
\hline 10 & KEC & 100 & $\mathrm{~T}$ & - \\
\hline 11 & $\mathrm{KSN}$ & 80 & $\mathrm{~T}$ & - \\
\hline 12 & LVR & 100 & $\mathrm{~T}$ & - \\
\hline 13 & LNU & 60 & - & TT \\
\hline 14 & LAG & 75 & $\mathrm{~T}$ & - \\
\hline 15 & $\mathrm{M}$ & 60 & - & $\mathrm{TT}$ \\
\hline 16 & MF & 78 & $\mathrm{~T}$ & - \\
\hline 17 & $\mathrm{M}$ & 80 & $\mathrm{~T}$ & - \\
\hline 18 & NJA & 100 & $\mathrm{~T}$ & - \\
\hline 19 & NMRA & 100 & $\mathrm{~T}$ & - \\
\hline 20 & ND & 75 & $\mathrm{~T}$ & - \\
\hline 21 & RK & 79 & $\mathrm{~T}$ & - \\
\hline 22 & RMW & 100 & $\mathrm{~T}$ & - \\
\hline 23 & RNGP & 60 & - & TT \\
\hline 24 & SSA & 77 & $\mathrm{~T}$ & - \\
\hline 25 & $\mathrm{TT}$ & 100 & $\mathrm{~T}$ & - \\
\hline 26 & YRKP & 82 & $\mathrm{~T}$ & - \\
\hline 27 & YDNS & 100 & $\mathrm{~T}$ & - \\
\hline
\end{tabular}

\begin{tabular}{llll}
\hline & Nama & Nilai & \multicolumn{2}{c}{ Kriteria } \\
\cline { 3 - 4 } & Siswa & Tuntas & $\begin{array}{c}\text { Tidak } \\
\text { Tuntas }\end{array}$ \\
\hline
\end{tabular}

\begin{tabular}{llll}
\hline Jumlah & 2270 & 22 & 5 \\
\hline Rata-rata & & 84,07 & \\
\hline Ketuntasan & & 81,48 & \\
Klasikal & & \\
\hline
\end{tabular}

Berdasarkan tabel diketahui bahwa skor terendah 60 dan skor tertinggi 100. Jumlah siswa yang tidak tuntas atau belum mencapai KKM sebanyak 5 siswa, sehingga persentase ketuntasan atau daya serap klasikal adalah sebagai berikut:

$$
\text { Persentase }=\frac{\text { Jumlah siswa yang tuntas }}{\text { Jumlah siswa keseluruhan }} \times 100 \%
$$

Persentase $=\frac{22}{27} \times 100 \%=81,48 \%$

Ketuntasan belajar secara klasikal yang dicapai pada siklus II ini sebesar $81,48 \%$, sehingga dapat dikatakan kelas tersebut belum tuntas belajar, karena belum mencapai $85 \%$ siswa yang mencapai ketuntasan. Kemudian rata-rata kelas dapat dihitung sebagai berikut:

Rata - rata $=\frac{\text { Jumlah semua nilai siswa }}{\text { Jumlah siswa }}$

Rata - rata $=\frac{2270}{27}=84,07$

Rata-rata kelas yang dicapai pada siklus II ini sebesar 84,07 sehingga dapat dikatakan ratarata kelas belum maksimal, karena belum mencapai 85. Berdasarkan hasil observasi dan hasil evaluasi yang diperoleh pada siklus II, ada beberapa catatan penting yang harus diperhatikan, antara lain:

1. Siswa lebih aktif dan mendalam dalam menyimak video dengan media Wirecast tersebut dibandingkan dengan siklus I.

2. Waktu 55 menit untuk menyimak video adalah proporsional dan cukup

3. Ketua kelompok (sang leader) mulai terbiasa dengan media Wirecast dan dapat mengondisikan anggota kelompoknya.

4. Pelaksanaan Tindakan Siklus III

Pada pelaksanaan tindakan untuk siklus 
yang ke III ini penerapan tindakan berulang sama seperti siklus ke II, yaitu tetap menggunakan media Wirecast tetapi ketua kelompok (sang leader) kembali ke posisi semula seperti siklus I, karena sang leader ini berhasil meningkatkan nilai prestasinya dan anggota kelompoknya juga berhasil meningkatkan nilai prestasinya meskipun ada beberapa siswa yang belum mampu untuk meningkatkannya. Hal ini adalah tugas dari semua anggota kelompok untuk memberikan motivasi dan semangat belajar bagi siswa tersebut dan tugas dari sang leader adalah berusaha semaksimal mungkin untuk menjelaskan dengan rinci materi tersebut serta sabar kepada anggota kelompoknya, sehingga di sini terjadi kerjasama yang baik antara anggota kelompok dengan sang leader.

\section{Analisis Data Siklus III}

Berdasarkan pemeriksaan hasil tes pada siklus III disajikan seperti tabel di bawah ini:

Tabel 3 Tabel Hasil Belajar siswa pada Siklus III

\begin{tabular}{lllcc}
\hline \multirow{2}{*}{ No } & $\begin{array}{l}\text { Nama } \\
\text { Siswa }\end{array}$ & & Nilai & \multicolumn{2}{c}{ Kriteria } \\
\cline { 3 - 5 } 1 & ABG & 95 & $\mathrm{~T}$ & $\begin{array}{c}\text { Tidak } \\
\text { Tuntas }\end{array}$ \\
\hline 2 & AAN & 100 & $\mathrm{~T}$ & - \\
\hline 3 & AW & 100 & $\mathrm{~T}$ & - \\
\hline 4 & DIS & 100 & $\mathrm{~T}$ & - \\
\hline 5 & DA & 100 & $\mathrm{~T}$ & - \\
\hline 6 & FR & 95 & $\mathrm{~T}$ & - \\
\hline 7 & FBS & 100 & $\mathrm{~T}$ & - \\
\hline 8 & GAA & 100 & $\mathrm{~T}$ & - \\
\hline 9 & IAL & 95 & $\mathrm{~T}$ & - \\
\hline 10 & KEC & 100 & $\mathrm{~T}$ & - \\
\hline 11 & KSN & 100 & $\mathrm{~T}$ & - \\
\hline 12 & LVR & 100 & $\mathrm{~T}$ & - \\
\hline 13 & LNU & 80 & $\mathrm{~T}$ & - \\
\hline 14 & LAG & 100 & $\mathrm{~T}$ & - \\
\hline 15 & M & 70 & - & TT \\
\hline
\end{tabular}

\begin{tabular}{lllcc}
\hline \multirow{2}{*}{ No } & $\begin{array}{c}\text { Nama } \\
\text { Siswa }\end{array}$ & & Nilai & \multicolumn{2}{c}{ Kriteria } \\
\cline { 3 - 5 } 16 & MF & 95 & $\mathrm{~T}$ & $\begin{array}{c}\text { Tidak } \\
\text { Tuntas }\end{array}$ \\
\hline 17 & M & 100 & $\mathrm{~T}$ & - \\
\hline 18 & NJA & 100 & $\mathrm{~T}$ & - \\
\hline 19 & NMRA & 100 & $\mathrm{~T}$ & - \\
\hline 20 & ND & 80 & $\mathrm{~T}$ & - \\
\hline 21 & RK & 100 & $\mathrm{~T}$ & - \\
\hline 22 & RMW & 100 & $\mathrm{~T}$ & - \\
\hline 23 & RNGP & 90 & $\mathrm{~T}$ & - \\
\hline 24 & SSA & 100 & $\mathrm{~T}$ & - \\
\hline 25 & TT & 100 & $\mathrm{~T}$ & - \\
\hline 26 & YRKP & 100 & $\mathrm{~T}$ & - \\
\hline 27 & YDNS & 100 & $\mathrm{~T}$ & - \\
\hline Jumlah & 2600 & 26 & 1 \\
\hline Rata-rata & & 96,29 & \\
\hline Ketuntasan & & $\mathbf{9 6 , 2 9}$ & \\
Klasikal & & & \\
\hline
\end{tabular}

Berdasarkan tabel maka tes siklus III nilai terendah 70 dan nilai tertinggi mencapai 100 dan 1 siswa yang belum mencapai nilai KKM yaitu 75, maka persentase ketuntasan klasikal adalah sebagai berikut:

Persentase $=\frac{\text { Jumlah siswa yang tuntas }}{\text { Jumlah siswa keseluruhan }} \times 100 \%$

Persentase $=\frac{26}{27} \times 100 \%=96,29 \%$

Berdasarkan perhitungan di atas bahwa ketuntasan belajar secara klasikal siswa kelas X MIPA 1 sebesar 96,29\%. Hal ini menunjukkan siswa kelas X MIPA 1 telah mengalami ketuntasan belajar karena daya serapnya mencapai 96,29\%, sehingga penelitian ini cukup sampai pada siklus III. Kemudian ratarata kelas dapat dihitung sebagai berikut:

$$
\begin{gathered}
\text { Rata }- \text { rata }=\frac{\text { Jumlah semua nilai siswa }}{\text { Jumlah siswa }} \\
\text { Rata }- \text { rata }=\frac{26}{27}=96,29
\end{gathered}
$$


Rata-rata kelas yang dicapai pada siklus III ini sebesar 96,29 sehingga dapat disimpulkan ratarata kelas telah mencapai ketuntasan, karena telah mencapai nilai di atas 85. Berdasarkan hasil observasi dan hasil evaluasi yang diperoleh pada siklus III, ada beberapa catatan penting yang harus diperhatikan, antara lain:

1. Pembelajaran dengan media Wirecast ini berlangsung dengan baik dan sangat menyenangkan bagi siswa

2. Waktu 90 menit sangat cukup bagi siswa dan bukan masalah lagi bagi siswa

3. Hasil belajar siswa mengalami peningkatan ini bisa dilihat dari nilai rata-rata

\section{Hasil Analisis Respons Siswa}

Berdasarkan angket mengenai respons siswa terhadap pelaksanaan proses pembelajaran dengan menggunakan media Wirecast skor ratarata untuk respons siswa terhadap penggunaan media Wirecast sebesar 89,11 \% atau berada pada skala sikap sangat setuju atau sangat berminat.

\section{Pembahasan}

Berdasarkan Standar Nasional Pendidikan (Peraturan Pemerintah Republik Indonesia Nomor 19 tahun 2005) maka tepat kiranya jika peneliti menggunakan media Wirecast untuk menggali potensi peserta didik dalam meningkatkan prestasi siswa. Media Wirecast merupakan media yang dapat memotivasi siswa untuk aktif dalam pembelajaran, dan menciptakan kemandirian siswa dalam belajar karena penggunaan media Wirecast ini akan membuat siswa lebih kreatif dan inovatif dalam menerapkan pengalaman metode belajarnya secara langsung kepada teman-temannya. Tiap leader mempunyai cara dan metode sendirisendiri dalam menjelaskan suatu konsep Fisika. Selain itu dengan media Wirecast yang lebih mengutamakan diskusi dalam kelompok, akan terjalin kerjasama yang baik antara siswa dan sekaligus memberikan pengalaman mengajar bagi sang leader. Jika dilihat dari ketuntasan belajar siswa, dimana ketuntasan kelas setiap siklus dari hasil penelitian adalah siklus 1 sebesar $62,96 \%$, siklus II sebesar $81,48 \%$ dan siklus III sebesar 96,29\%. Dengan demikian pengelolaan pembelajaran yang telah dilakukan oleh guru cenderung meningkat. Berdasarkan angket respons siswa terhadap pengelolaan pembelajaran dengan menggunakan media Wirecast ini berada pada skala sikap sangat setuju atau sebesar $89,11 \%$.

\section{Kesimpulan dan Saran}

\section{Kesimpulan}

Berdasarkan hasil penelitian dan pembahasan, dapat disimpulkan:

Penggunaan media Wirecast ini dapat meningkatkan prestasi belajar siswa pada pelajaran Fisika konsep Listrik Dinamis siswa kelas X MIPA 1 SMA Negeri 2 Probolinggo.

Secara umum respon siswa terhadap penggunaan media Wirecast ini sangat baik.

\section{Saran}

Berdasarkan kesimpulan, maka terdapat beberapa saran yang perlu dipertimbangkan, antara lain:

Bagi pendidik yang ingin menggunakan media Wirecast ini perlu kiranya memperhatikan atau mempertimbangkan hal-hal, seperti: alat, kesiapan guru, inovasi guru dan ketersediaan waktu.

Bagi peneliti yang berminat menggunakan media Wirecast ini dapat dikembangkan lebih lanjut pada konsep yang lain dalam mata pelajaran Fisika

\section{Daftar Rujukan}

Asmara. (2009). Prestasi Belajar. Bandung: PT. Remaja Rosdakarya

Asyar, Rayanda. (2012). Kreatif Mengembangkan Media Pembelajaran, Jakarta: Gaung Persada (GP) Press Jakarta

Hamalik, O. (2008). Kurikulum dan Pembelajaran. Jakarta: Sinar rafika

Kanginan, M. 2006. Fisika untuk SMA Kelas $X$ Semester 2 jilid $1 B$. Jakarta: Erlangga. 
Kemmis, S \& Mc Taggart, R. (1992). The Action Reseacrh Planner, Australia: Deakin University Press 